Proceedings of the 10th International Ruminant Reproduction Symposium (IRRS 2018); Foz do Iguaçu, PR, Brazil, September 16th to 20th, 2018.

\title{
The life and death of the dominant follicle
}

\author{
Christopher A. Price*, Anthony Estienne \\ Centre de Recherche en Reproduction et Fertilité, Faculty of Veterinary Medicine, University of Montreal, \\ St-Hyacinthe, QC, Canada.
}

\begin{abstract}
Much work has been conducted over the years to determine the major factors that control follicle growth, including the role of FSH, LH and IGF1. These factors permit the dominant follicle to grow while subordinate follicles regress. The dominant follicle enters a phase of growth, and then that growth slows as the follicle reaches maximum size. The dominant follicle remains morphologically larger for a few days in the static phase, before starting to regress with the loss of functional dominance. Few studies have addressed the factors that determine follicle fate during the static phase. In this review, we summarize the differences in gene expression between growing and non-growing (static or early regressing) dominant follicles, highlighting areas that require further study. Potential factors that may help survival of the dominant follicle include IGF1, estradiol and BMP4/BMP7, and intrafollicular factors that likely initiate regression and apoptosis include FGF18 and AMH acting through FASLG. It is also very likely that the influence of microRNAs, especially miR-21, play a role in determining the fate of the dominant follicle.
\end{abstract}

Keywords: apoptosis, atresia, follicle, granulose.

\section{Introduction}

The bovine dominant follicle, once established, continues to grow from about 9 to $15 \mathrm{~mm}$ diameter over the course of about 4 days, then enters a 4 to 5 -day plateau or static phase with little further growth, after which it starts to regress concomitantly with the recruitment of a new follicle wave. The dynamics of dominant follicle growth and gonadotropin control of the establishment of follicular dominance in ruminants have been extensively reviewed (Ireland et al., 2000; Ginther, 2016; Shimizu, 2016; Webb et al., 2016). The growing dominant follicle is highly estrogenic and the granulosa cells proliferate as the follicle increases in diameter, initially under the influence of FSH. As plasma FSH concentrations decline, the continued growth of the follicle is supported by LH and IGF1 (Shimizu, 2016). As the follicle reaches the end of the growth phase, intrafollicular concentrations of estradiol decrease (Ireland and Roche, 1983; Badinga et al., 1992; Price et al., 1995) and the follicle enters the static phase.

It is well known that the dominant follicle is functionally as well as morphologically dominant, as it suppresses the development of smaller follicles; ablation of the dominant follicle allows immediate recruitment of a new follicle wave or can rescue the regressing subordinate follicle if performed early during the growth of the dominant follicle (Ko et al., 1991;
Siddiqui et al., 2015). The static phase, despite its name, is a period of change for the dominant follicle and the fate of the follicle is decided during this time. Early static dominant follicles are estrogen-active and approximately half of static dominant follicles are morphologically healthy by light microscopy (Price et al., 1995; Irving-Rodgers et al., 2001), and they frequently respond to induced luteolysis by ovulating (Ali et al., 2001). In contrast, the late static dominant follicle is estrogen-inactive, mostly atretic and fails to ovulate after luteolysis (Ali et al., 2001; Irving-Rodgers et al., 2001). Therefore, the static phase is a plastic period of the dominant follicle lifespan during which the fate of the follicle is determined.

To determine the mechanisms of follicle growth and regression, many studies have been performed comparing growing dominant with regressing subordinate follicles of the same wave. Although these studies are of great value and have identified many characteristics of growth and regression, they do not address the 'static' phase of the dominant follicle lifespan. The purpose of this review is to summarize our understanding of the physiology of late growing, static and early regressing dominant follicles in cattle (Bos taurus), with reference to other species where appropriate, and to explore potential intrafollicular mechanisms that may determine follicle fate during the static phase. Several factors involved in early dominant follicle growth are described out of necessity when data for the late growing/static phase are unavailable.

\section{Gene expression patterns in late growing, static \& early regressing dominant follicles}

Numerous studies of the expression of candidate genes and of global transcriptomics have been performed comparing granulosa cells from dominant follicles and from subordinate follicles during and after selection in cattle (reviewed in Zielak-Steciwko and Evans, 2016), but less attention has been paid to the different phases of dominant follicle growth. An early series of studies measured steroidogenic enzyme and gonadotropin receptor mRNA levels by in-situ hybridization (reviewed in Bao and Garverick, 1998), and as follicle growth slowed in healthy dominant follicles (from day 4 to 6 after wave emergence), there were decreases in CYP11A1 mRNA levels in theca and granulosa cells, and of CYP17A1 and LHCGR in theca cells. These same studies demonstrated that atretic dominant follicles contained less CYP19A1 and LHCGR mRNA in the granulosa cell layer compared to healthy dominant follicles of the same size. In a later study, a comparison between dominant follicles in the early and late growing phases, from day 2 to day 5.5 after wave 
emergence, demonstrated that as the dominant follicle reaches maximum diameter, granulosa FSHR mRNA levels decrease and $L H C G R$ mRNA levels increase (Mihm et al., 2006), however this study included a number of smaller follicles that were no larger than the next subordinate follicle.

Other candidate gene studies have revealed that some fibroblast growth factors have been shown to differ between healthy and atretic dominant follicles; FGF18 is expressed in theca cells and mRNA levels are higher in atretic compared with healthy large follicles and in subordinate vs dominant follicles (Portela et al., 2010). FGF9 is predominantly expressed in granulosa cells and mRNA levels are higher in atretic compared with healthy large follicles (Schütz et al., 2016). In contrast, thecal FGF2 and FGF10 mRNA levels have been reported to be higher in healthy compared to atretic bovine follicles of abattoir origin (Berisha et al., 2004; Buratini et al., 2007).

Some members of the bone morphogenetic protein family also change with follicle health: Glister et al. demonstrated that granulosa cell $B M P 2 \mathrm{mRNA}$ levels decreased as follicle size increased (from 7 to $18 \mathrm{~mm}$, abattoir ovaries; Glister et al., 2010) whereas Selvaraju at al. showed that BMP2 mRNA levels increase as dominant follicles progressed from pre- to middominance ( 8 - $16 \mathrm{~mm}$; timed collection) and remained high in static phase follicles (Selvaraju et al., 2013). Comparing estrogen-active and inactive large follicles, granulosa cell $B M P 2 \mathrm{mRNA}$ levels were higher in large atretic follicles compared to large healthy follicles (Glister et al., 2010). This latter study also showed that $B M P 4, B M P 6$ and $B M P 7$ mRNA levels did not differ between healthy and unhealthy large follicles.

Cocaine- and amphetamine-regulated transcript (CARTPT) mRNA levels are very low in granulosa cells of dominant follicles in cattle compared with preselection follicles and do not change during dominant follicle growth (Lv et al., 2009). Unfortunately, data are not available for these genes in growing, static and early regressing dominant follicles.

Two studies have investigated the follicular transcriptome during the late growing/static phase of the dominant follicle lifespan. In one study, the static phase was mimicked in cows by stimulating with FSH followed by a 'coasting' period; in this model, the abundance of multiple mRNA species changed as the follicle coasts, with most changes reflecting an increase in genes encoding anti-proliferative and pro-apoptotic proteins as the static phase progresses (Nivet et al., 2013). In a study of follicles $>9 \mathrm{~mm}$ diameter grouped as growing, static and regressing by flow cytometry, microarray analysis identified a number of genes that were differentially expressed between the three groups, suggesting that the follicles undergo distinct changes rather than a gradual slide from healthy to atretic (Girard et al., 2015). In this latter study, BMP4 mRNA levels were not different between growing, static and regressing dominant follicles, in agreement with Glister et al. (2010).

MicroRNAs have also been the target of profiling during follicle growth. Using large bovine follicles of abattoir origin, 57 miRNA were differently expressed in estrogen-active compared to estrogeninactive follicles (Sontakke et al., 2014). In a study comparing the dominant and subordinate follicles on day 3 and day 7 of the cycle, Salilew-Wondim and colleagues found few (16) differentially expressed miRNA between dominant and subordinate follicles on day 3 , and a larger number (108) differentially expressed on day 7 (SalilewWondim et al., 2014). A direct comparison of dominant follicles on day 3 (growing) and day 7 (static or regressing) identified 131 differentially expressed miRNA in granulosa cells (Salilew-Wondim et al., 2014). The number of miRNA that were differentially expressed in both these datasets is small (Table 1), which might be a reflection of the different biological models used.

A study comparing preovulatory dominant follicles with subordinate follicles identified 34 miRNA enriched and 30 miRNA reduced in granulosa cells of preovulatory follicles compared to subordinate follicles; interestingly, PCR analysis indicated that selected miRNA differentially expressed in granulosa cells were also differentially expressed in theca cells (Gebremedhn et al., 2015). Preovulatory follicles would be expected to be different from non-ovulatory dominant follicles owing to the considerable increase in oestradiol levels and LH pulse frequency as well as a decrease in peripheral progesterone levels, so this particular comparison is not so relevant for the current discussion.

No global profiling has yet been reported for theca cells during this stage of follicle growth. A microarray study compared the theca cells of healthy and atretic follicles 3-5 mm diameter of abattoir origin, and concluded that most differentially expressed genes were related to inflammation and vascularization rather than apoptosis (Hatzirodos et al., 2014).

A glycoproteomic study was conducted with bovine granulosa and theca samples and atresia was associated with increased levels of certain sulphated chondroitin polysaccharides in granulosa cells and of sulphated heparan polysaccharides in theca cells (Hatzirodos et al., 2012). It is not known whether such changes occur during the growing-static-regressing phases of the dominant follicle.

Table 1. MicroRNA identified in both Sontakke et al. (2014) and Salilew-Wondim et al. (2014) as differentially expressed between growing and non-growing large follicles.

\begin{tabular}{ll}
\hline Upregulated in growing follicles & Upregulated in non-growing follicles \\
\hline bta-miR-202 & bta-miR-149-3p \\
bta-miR-31 & bta-miR-21 \\
bta-miR-873 & bta-miR-150 \\
bta-miR-652 & bta-miR-204-3p \\
bta-miR-450b & bta-miR-409a \\
bta-miR-15b & bta-miR-142 \\
bta-miR-424-p5 & \\
\hline
\end{tabular}


Prolonging the life of the dominant follicle

\section{FSH, IGF1 and estradiol}

FSH is a major folliculogenic factor and administration of exogenous FSH induces the growth of multiple dominant follicles in a superovulatory setting; lower levels of FSH are also able to maintain the growth of 2 dominant follicles and/or delay regression of subordinate follicles (Adams et al., 1993; Mihm et al., 1997; Rivera and Fortune, 2001). This is likely to be caused by stimulation of the early growth phase of the dominant follicle which permits the selection of multiple dominant follicles. Once the dominant follicle is established it can remain viable in the face of low circulating FSH concentrations, and continue to grow past its normal lifespan if pulsatile LH secretion is increased (Stock and Fortune, 1993; Bigelow and Fortune, 1998). A regressing dominant follicle (as well as subordinate follicles) can also be rescued if FSH levels are increased (Ginther et al., 2016).

Intrafollicular estradiol is another major player involved in follicle health. It is well known that estradiol increases proliferation of granulosa cells of numerous species (Drummond and Findlay, 1999; Rosenfeld et al., 2001), enhances cell cycle progression from G1 to S phase (Quirk et al., 2006), and protects cells against FASLG- and FGF18-induced apoptosis (Quirk et al., 2006; Portela et al., 2015). It should be noted here that exogenously administered systemic estradiol induces atresia of the dominant follicle (Burke et al., 2005) by reducing LH pulse amplitude as well as FSH secretion (Price and Webb, 1988).

Although IGF1 is probably best known for its role in follicle deviation and the establishment of dominance, it also likely plays a role in supporting dominant follicle survival through regulation of IGF binding proteins (IGFBP) and hence IGF1 bioactivity (Mazerbourg and Monget, 2018). Large estrogen-active sheep and cattle follicles contain lower levels of IGFBPs - and thus higher IGF bioavailability - than do smaller growing or atretic follicles (Besnard et al., 1996; Roberts and Echternkamp, 2003), and addition of IGF1 to granulosa cells increased cell proliferation and estradiol secretion in a follicle-size specific manner (Monniaux and Pisselet, 1992; Gong et al., 1993; Spicer et al., 1993).

\section{The transforming growth factor- $\beta$ (TGF $\beta$ ) family}

The TGF $\beta$ superfamily roles in ovarian function are critical and complex, and it seems that the disappearance of one of them or a disturbance of the equilibrium formed by these factors will strongly influence folliculogenesis and then ovulation. The role of TGF $\beta$ superfamily members in preantral follicle development and follicle selection has been reviewed (Knight and Glister, 2006).

Two BMPs, BMP4 and BMP7, are generally considered to be theca-derived proteins that act on granulosa cells. In cattle, both BMP4 and BMP7 mRNA are detected predominantly in theca cells (Fatehi et al.,
2005; Glister et al., 2010), whereas in sheep neither BMP4 nor BMP7 mRNA were detected in follicles by in-situ hybridization (Juengel et al., 2006). Neither BMP4 nor BMP7 mRNA levels appear to be regulated by LH in bovine theca cells (Glister et al., 2011).

In vitro studies have shown that these BMPs affect granulosa cell steroidogenesis and proliferation. Theca-derived BMP4 and BMP7 increased granulosa proliferation and estrogen secretion, and inhibited progesterone synthesis in some studies with ruminants (Glister et al., 2004), but did not alter granulosa proliferation in another study (Yamashita et al., 2011). The effect of BMP7 on progesterone synthesis is due to a reduction of STAR mRNA levels (Yamashita et al., 2011). These BMPs may also promote follicle development/survival by increasing granulosa cell VEGF secretion and angiogenesis (Shimizu et al., 2012). Paradoxically, BMP4 and BMP7 potently inhibit androgen secretion from bovine theca cells (Glister et $a l ., 2005)$ and as levels of neither appear to change with follicle health (Glister et al., 2010), the physiological role of these proteins remains to be established.

Levels of granulosa cell $B M P 2$ mRNA were lower in estrogen active dominant follicles compared with smaller growing follicles, and tended to increase in atretic follicles in cattle (Glister et al., 2010), and in sheep BMP2 mRNA was only detected by in-situ hybridization in atretic follicles (Juengel et al., 2006). In contrast, $B M P 2$ mRNA levels were higher in large estrogen active dominant follicles compared with smaller growing follicles in water buffalo (Rajesh et al., 2018). Addition of recombinant BMP2 increased estradiol secretion but decreased progesterone secretion from ovine and bovine granulosa cells in vitro without altering cell proliferation (Souza et al., 2002; Juengel et al., 2006; Selvaraju et al., 2013).

Two other BMPs of interest are BMP15 and GDF9, which are expressed in the oocyte. GDF9 is critical for primary follicle growth and knock-out of Gdf9 in the mouse results in arrest of folliculogenesis at the primary stage (Dong et al., 1996). In sheep, the role of GDF9 appears similar because in the case of a natural loss of function mutation of GDF9 in several breeds of ewes show abnormal folliculogenesis with arrest of follicle development at the primary stage (Nicol et al., 2009). Loss of Bmpl5 in mice results in reduced litter size owing to ovulation defects (Yan et al., 2001). In sheep there are several natural mutations that alter antral follicle growth, including $F e c X^{I}, F e c X^{R}$ and $F e c X^{L}$, for which homozygous ewes are sterile with follicle arrest at the primary stage whereas ewes heterozygous for this same mutation have increased ovulation rate (Galloway et al., 2000; Bodin et al., 2007; Martinez-Royo et al., 2008). Another mutation in the BMP subfamily, called $F e c B$, is in the coding sequence of the $B M P R 1 B$ gene and induces a partial loss of function of this BMP receptor which leads to increased ovulation rate (Souza et al., 2001) and influences the proliferation and steroidogenesis of granulosa cells (Mulsant et al., 2001; Campbell et al., 2006). Recently, a mutation in a BMP signalling pathway termed 'Trio' has and been described in cattle, which results in increased SMAD6 mRNA 
levels and, similar to the situation in sheep, in the growth and survival of two or more dominant follicles (Garcia-Guerra et al., 2018).

Both BMP15 and GDF9 affect granulosa cell proliferation and steroidogenesis, but in complex species-specific patterns. Recombinant BMP15 stimulated granulosa cell proliferation in ruminants (McNatty et al., 2005) and protects granulosa and cumulus cells against apoptosis in ruminants (Hussein et al., 2005). In sheep and cattle, BMP15 and GDF9 have been reported to inhibit FSH-induced progesterone synthesis by granulosa cells (McNatty et al., 2005; Fabre et al., 2006), although species of origin of the protein has been reported to alter its effect: ovine GDF9 inhibited progesterone secretion from sheep granulosa cells whereas mouse GDF9 increased progesterone secretion (McNatty et al., 2005). There is also a species difference in the amounts of BMP15/GDF9 secreted by the oocyte of polyovular vs monovular species, as sheep secrete both whereas rats secrete primarily GDF9 (Lin et al., 2012). BMP15 and GDF9 synergize, and this may be in the form of secreted heterodimers (cumulin) or secreted monomeric proteins that form dimers at the receptor of the target cell (Mottershead et al., 2015; Heath et al., 2017).

There is also evidence that GDF9 can alter theca cell function in pre-selection follicles, as it decreased proliferation and steroidogenesis of bovine theca cells from follicles $<6 \mathrm{~mm}$ diamater, but had no effect on theca cells from follicles $>8 \mathrm{~mm}$ diameter (Spicer et al., 2008).

\section{Induction of atresia in the dominant follicle}

The fate of the dominant follicle is determined during the static phase of development, and the follicle can regress and become atretic 'passively' if the survival signals described above are reduced/absent. However, it is not clear what endocrine changes occur between the end of the growing period and the end of the static period. Alternatively, intrafollicular events may predispose a follicle toward atresia; the following section describes some potential pro-apoptotic factors that may play a role in determining the fate of the dominant follicle.

\section{Fas antigen and Fas ligand}

Fas antigen is a transmembrane receptor which induces apoptosis when activated by the protein Fas ligand (FASLG). In cattle, granulosa cell FAS mRNA levels were not different between growing and atretic dominant follicles, but were significantly higher in the theca layer of atretic compared with healthy dominant follicles (Porter et al., 2000). FASLG mRNA levels are also higher in atretic vs healthy follicles in nonruminants, and can be increased in ruminant granulosa and theca cells in vitro by treatments that increase apoptosis including serum withdrawal (Hu et al., 2001), FGF18 (Portela et al., 2015) and toxins (Guerrero-Netro et al., 2015, 2017). Alone, FASLG does not cause apoptosis in granulosa cell cultures with serum but requires the presence of IFN gamma - however, in serumfree culture, bovine GC are susceptible to FASL-induced apoptosis (Quirk et al., 2000), although this was prevented in the presence of IGF, FGF2 and EGF, but not FGF7, TGF, PDGF or gonadotropins (Quirk et al., 2000).

In rodents, Faslg induces granulosa cell death and decreased levels of inducible nitric oxide synthase (Nos2) mRNA levels, and this can be prevented by nitric oxide (Chen et al., 2005). In cattle, inhibition of endogenous NO production increased FASLG expression and granulosa cell apoptosis (Zamberlam et al., 2011). Estradiol stimulated NOS2 mRNA levels in bovine granulosa cells (Zamberlam et al., 2011) and also attenuates FASLG-induced apoptosis (Quirk et al., 2006). It seems likely that FASLG is a mediator of apoptosis induced by various effectors.

\section{Fibroblast growth factors}

FGF18 has been clearly demonstrated as a proapoptotic factor. This member of the fibroblast growth factor family is produced in vivo by the theca layer in cattle, and protein and mRNA levels are higher in atretic compared with healthy follicles. Moreover, recombinant FGF18 inhibits granulosa cell estradiol secretion and abundance of CYP19A1, CYP11A1, HSD17ß1, STAR, HSD3 $\beta 1$ and FSHR mRNA (Portela et al., 2010), and increases DNA fragmentation and abundance of cleaved caspase-3 in granulosa cells (Portela et al., 2010, 2015; Fig. 1). Injecting FGF18 into the growing dominant follicle in vivo caused follicle regression (Portela et al., 2015). It is interesting to note here that some growth factors promote granulosa cell proliferation but decrease estradiol secretion in vitro, FGF9 for example (Schreiber and Spicer, 2012); this apparent paradox has been referred to a dedifferentiating effect, but proliferation of cells may be caused by growth factor activation of MAPK pathways that drive proliferation irrespective of lower estradiol levels.

In support of this notion, FGF18 appears not to activate the typical FGF signalling pathways in granulosa cells; specifically, FGF18 does not increase MAPK3/1 phosphorylation or abundance of typical FGF response genes including SPRY2 and EGR3 (Jiang et al., 2013; Han et al., 2017), although it does increase MAPK14 phosphorylation (Portela et al., 2015). The mechanism of action of FGF18 remains obscure.

\section{The transforming growth factor- $\beta$ (TGF $\beta$ ) family}

Anti-Müllerian Hormone (AMH), another member of the TGF $\beta$ super-family, is secreted by granulosa cells of small follicles and is known to inhibit the recruitment of primordial follicles in rodents (Durlinger et al., 1999) but not in sheep (Campbell et al., 2012). In ruminants, as in non-ruminant species, AMH levels decrease with increasing size of antral follicles, and appears to be inversely correlated with CYP19A1 expression (Monniaux et al., 2008; Campbell et al., 2012; Liang et al., 2016). Recombinant AMH decreases granulosa and theca cell steroidogenesis in vitro (Campbell et al., 2012), and has been shown to 
increase apoptosis in human granulosa tumour cells (Anttonen et al., 2011). AMH mRNA levels and protein secretion from granulosa cells in vitro are stimulated by BMP2, BMP4 and BMP6 in sheep and cattle (Rico et al., 2011; Estienne et al., 2015), and $A M H$ mRNA levels are increased by BMP15 in sheep granulosa cells, and GDF9 enhanced this effect (Pierre et al., 2016). At least part of the ability of the $F e c B$ mutation to decrease granulosa apoptosis may be the reduced expression of AMH mRNA and protein in this genotype (Fig. 2).

Fig $x$
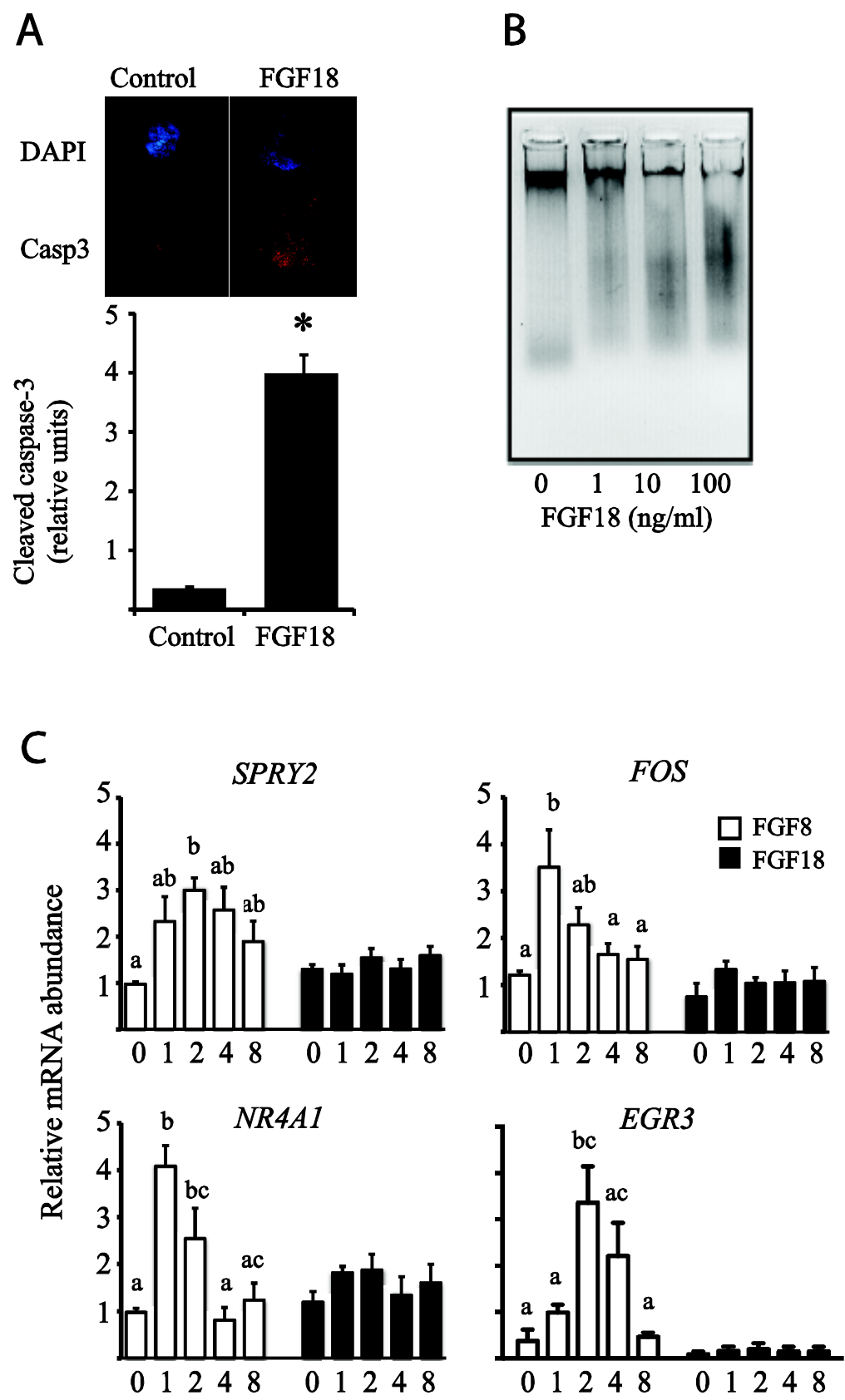

Time of treatment $(\mathrm{h})$

Figure 1. FGF18 increases apoptosis in granulosa cells and does not activate typical FGF signaling pathways. Culture of bovine granulosa cells with recombinant human FGF18 increases cleaved caspase-3 protein levels (A) and DNA fragmentation (B), and addition of FGF18 (10 ng/ml, filled bars) does not increase levels of mRNA of typical response genes (compare with FGF8; $10 \mathrm{ng} / \mathrm{ml}$, hollow bars). Bars with common letters are not statistically different. Data from (Portela et al., 2010, 2015; Jiang et al., 2013; Han et al., 2017). 

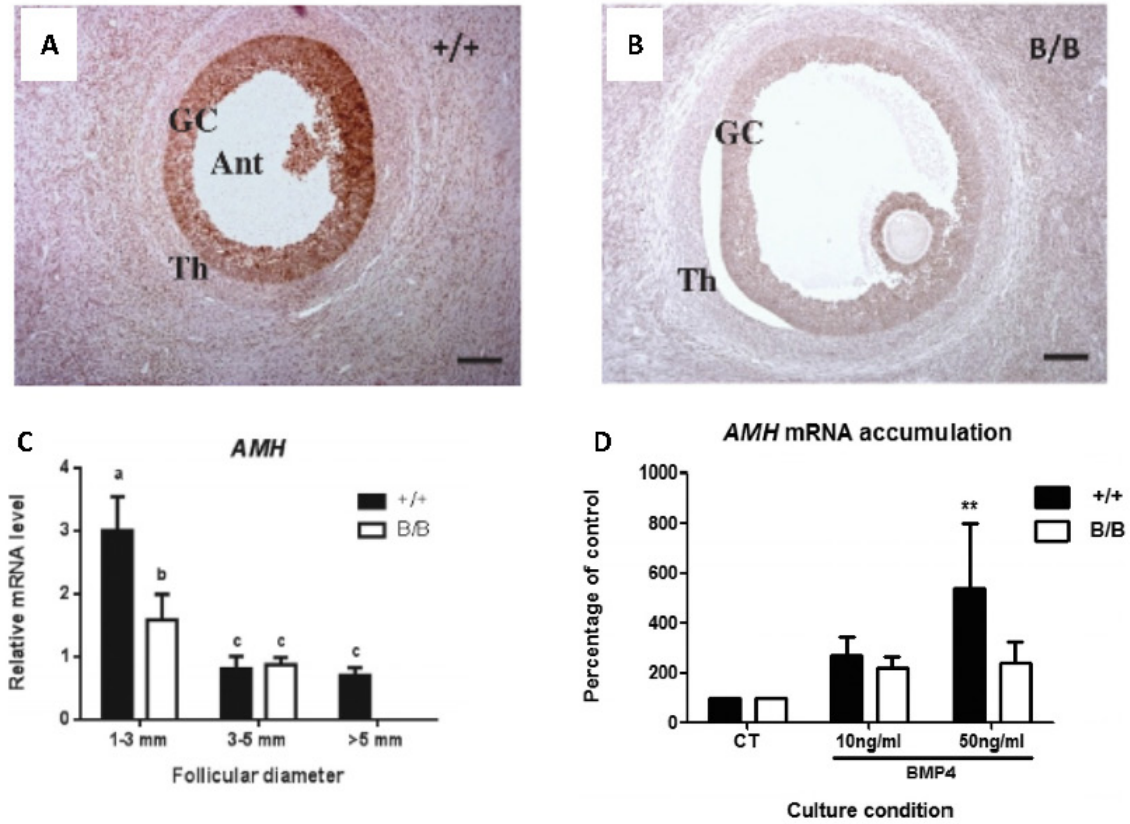

Figure 2. Regulation of AMH by BMPs in sheep follicles. Anti-Mullerian hormone protein (A,B) and mRNA (C) levels are markedly reduced in sheep carrying the hyperprolificacy Booroola mutation in BMPR1 compared to noncarriers, and this mutation leads to reduced granulosa cell responsiveness to BMP4 (D). Bars with common letters are not statistically different, and asterisks denote a significant stimulation of $A M H$ mRNA abundance by BMP4. Data from Estienne et al. (2015).

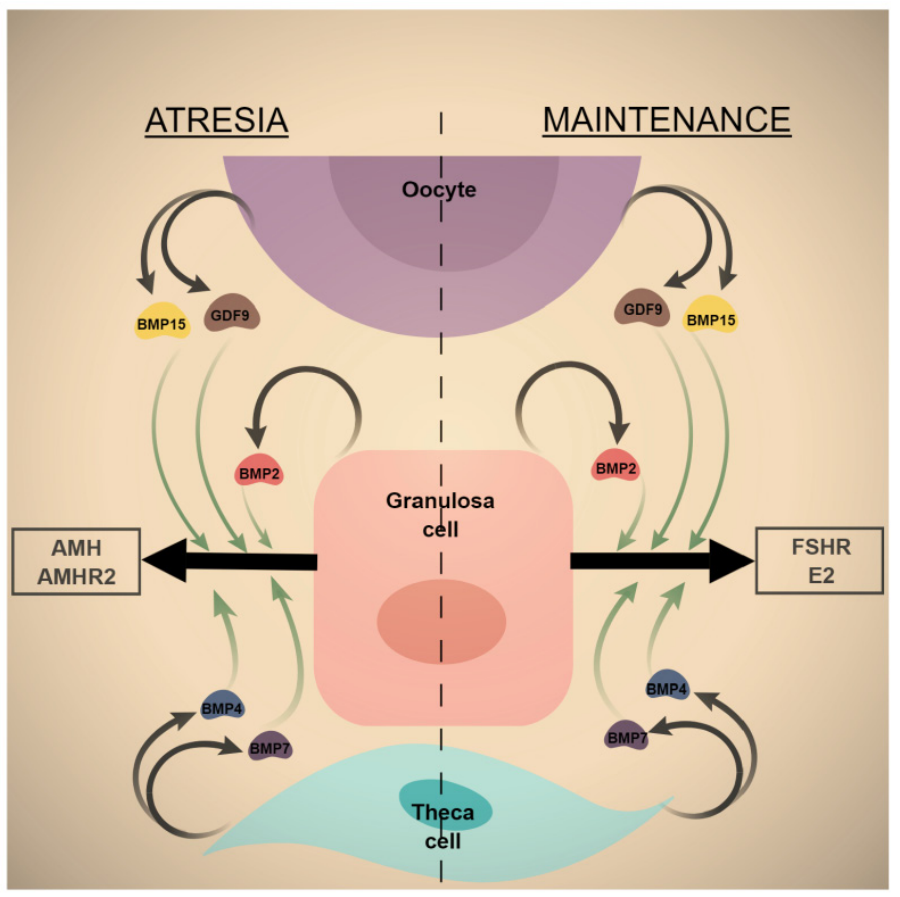

Figure 3. The duality of BMP action in the ovarian follicle. BMPs of theca, oocyte and granulosa cell origin have been shown to stimulate FSHR expression and estradiol secretion from granulosa cells, thus supporting granulosa cell survival and growth or maintenance of the dominant follicle. However, these same factors have also been shown to increase AMHR2 expression and AMH secretion, which is a pro-apoptotic signal. The net impact on the follicle is likely determined by other endocrine/paracrine factors present during the static phase of the dominant follicle lifespan.

miRNA

The roles of miRNA in dominant follicle development remain obscure. Some miRNA upregulated in atretic follicles (Table 1) have been shown to block apoptosis, including miR-21 in mouse granulosa cells (Carletti et al., 2010), miR-149 in lymphoma cells
(Fan et al.,2016) and miR-142 in cancer cells (Li et al., 2016). However, miR-150 promotes cell growth in ovarian cancer (Li et al., 2015) but causes apoptosis in lymphocytes (Sang et al., 2016) as well as endothelial cells. It is possible that these miRNAs are upregulated in atretic follicles as a defence against apoptosis, and are thus an effect of atresia rather than a cause. 


\section{Conclusions}

As growth of the dominant follicle slows, the follicle faces two possible fates: maintenance of growth/survival, and atresia. Increases in gonadotropin concentrations will drive survival, likely through increased intrafollicular estradiol, IGF1 and mRNA levels, and evidence is accumulating that other intrafollicular factors may either predispose the follicle to or provide protection against atresia. The proapoptotic factors likely include increased secretion of
AMH by granulosa cells and of FGF18 by theca cells, which increase FASLG-mediated apoptosis of granulosa cells and thus initiate an irreversible process of follicle atresia. The BMPs have been implicated, and they may help or hinder follicle survival depending perhaps on other endocrine or paracrine factors present. The potential role of each is summarized in Fig 4. Exactly when and how this fate determination occurs is unknown, and future research is required to determine the paracrine and autocrine events that occur within the follicle during the static phase of its lifespan.
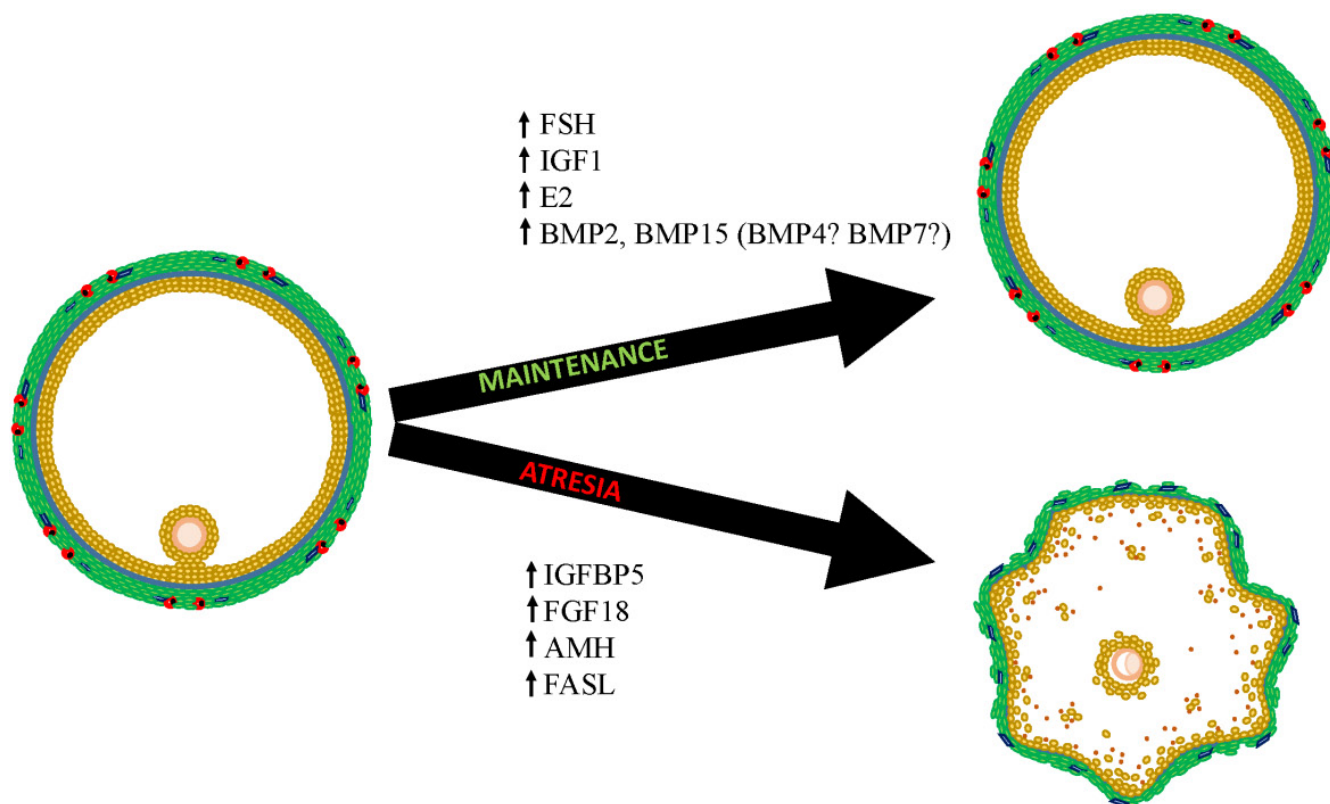

Figure 4. Schematic representation of the fate of the dominant follicle as it enters the static phase of its lifespan. The follicle may survive and go on to the preovulatory stage if appropriate gonadotrophic stimuli are provided. Alternatively, lack of gonadotropin support in combination with the secretion of local proapoptotic factors including but not limited to FGF18 and AMH may initiate FASLG-mediated granulosa cell apoptosis and irrevocably drive the follicle into regression.

\section{Acknowledgments}

We thank NSERC and FRQ-NT for funding the work from our laboratory, and apologize to all those whose work we were not able to cite in this short review.

\section{References}

Adams GP, Kot K, Smith CA, Ginther OJ. 1993. Selection of a dominant follicle and suppression of follicular growth in heifers. Anim Reprod Sci, 30:259271.

Ali A, Lange A, Gilles M, Glatzel PS. 2001 Morphological and functional characteristics of the dominant follicle and corpus luteum in cattle and their influence on ovarian function. Theriogenology, 56:569576.

Anttonen M, Färkkilä A, Tauriala H, Kauppinen M, MacLaughlin DT, Unkila-Kallio L, Bützow R, Heikinheimo M. 2011. Anti-Müllerian hormone inhibits growth of AMH type II receptor-positive human ovarian granulosa cell tumor cells by activating apoptosis. Lab Invest, 91:1605-1614.
Badinga L, Driancourt MA, Savio JD, Wolfenson D, Drost M, de la Sota RL, Thatcher WW. 1992. Endocrine and ovarian responses associated with the first-wave dominant follicle in cattle. Biol Reprod, 47:871-883.

Bao B, Garverick HA. 1998. Expression of steroidogenic enzyme and gonadotropin receptor genes in bovine follicles during ovarian follicular waves: a review. J Anim Sci, 76:1903-1921.

Berisha B, Sinowatz F, Schams D. 2004. Expression and localization of fibroblast growth factor (FGF) family members during the final growth of bovine ovarian follicles. Mol Reprod Dev, 67:162-171.

Besnard N, Pisselet C, Zapf J, Hornebeck W, Monniaux D, Monget P. 1996. Proteolytic activity is involved in changes in intrafollicular insulin-like growth factor-binding protein levels during growth and atresia of ovine ovarian follicles. Endocrinology, 137:15991607.

Bigelow KL, Fortune JE. 1998. Characteristics of prolonged dominant versus control follicles: follicle cell numbers, steroidogenic capabilities, and messenger ribonucleic acid for steroidogenic enzymes. Biol Reprod, 58:1241-1249. 
Bodin L, Di Pasquale E, Fabre S, Bontoux M, Monget P, Persani L, Mulsant P. 2007. A novel mutation in the bone morphogenetic protein 15 gene causing defective protein secretion is associated with both increased ovulation rate and sterility in lacaune sheep. Endocrinology, 148:393-400.

Buratini J Jr, Pinto MGL, Castilho AC, Amorim RL, Giometti IC, Portela VM, Nicola ES, Price CA. 2007. Expression and function of fibroblast growth factor 10 and its receptor, fibroblast growth factor receptor 2B, in bovine follicles. Biol Reprod, 77:743750.

Burke CR, Cárdenas H, Mussard ML, Day ML. 2005. Histological and steroidogenic changes in dominant ovarian follicles during oestradiol-induced atresia in heifers. Reproduction, 129:611-620.

Campbell BK, Souza CJH, Skinner AJ, Webb R, Baird DT. 2006. ricoEnhanced response of granulosa and theca cells from sheep carriers of the FecB mutation in vitro to gonadotropins and bone morphogenic protein-2, -4, and -6. Endocrinology, 147:1608-1620

Campbell BK, Clinton M, Webb R. 2012. The role of anti-Müllerian hormone (AMH) during follicle development in a monovulatory species (sheep). Endocrinology, 153:4533-4543.

Carletti MZ, Fiedler SD, Christenson LK. 2010. MicroRNA 21 blocks apoptosis in mouse periovulatory granulosa cells. Biol Reprod, 83:286-295.

Chen Q, Yano T, Matsumi H, Osuga Y, Yano N, Xu J, Wada O, Koga K, Fujiwara T, Kugu K, Taketani Y. 2005. Cross-talk between Fas/Fas ligand system and nitric oxide in the pathway subserving granulosa cell apoptosis: a possible regulatory mechanism for ovarian follicle atresia. Endocrinology, 146:808-815.

Dong J, Albertini DF, Nishimori K, Kumar TR, Lu N, Matzuk MM. 1996. Growth differentiation factor-9 is required during early ovarian folliculogenesis. Nature, 383:531-535.

Drummond AE, Findlay JK. 1999. The role of estrogen in folliculogenesis. Mol Cell Endocrinol, 151:57-64.

Durlinger AL, Kramer P, Karels B, de Jong FH, Uilenbroek JT, Grootegoed JA, Themmen AP. 1999 Control of primordial follicle recruitment by antiMullerian hormone in the mouse ovary. Endocrinology, 140:5789-5796

Estienne A, Pierre A, di Clemente N, Picard J-Y, Jarrier P, Mansanet C, Monniaux D, Fabre S. 2015 Anti-Müllerian hormone regulation by the bone morphogenetic proteins in the sheep ovary: deciphering a direct regulatory pathway. Endocrinology, 156:301313.

Fabre S, Pierre A, Mulsant P, Bodin L, Di Pasquale E, Persani L, Monget P, Monniaux D. 2006 Regulation of ovulation rate in mammals: contribution of sheep genetic models. Reprod Biol Endocrinol, 4:20. doi: 10.1186/1477-7827-4-20

Fan S-J, Li H-B, Cui G, Kong X-L, Sun L-L, Zhao Y-Q, Li Y-H, Zhou J. 2016. miRNA-149* promotes cell proliferation and suppresses apoptosis by mediating JunB in T-cell acute lymphoblastic leukemia. Leuk Res, 41:62-70.
Fatehi AN, Van Den Hurk R, Colenbrander B, Daemen A, van Tol HTA, Monteiro RM, Roelen BAJ, Bevers MM. 2005. Expression of bone morphogenetic protein2 (BMP2), BMP4 and BMP receptors in the bovine ovary but absence of effects of BMP2 and BMP4 during IVM on bovine oocyte nuclear maturation and subsequent embryo development. Theriogenology, 63:872-889.

Galloway SM, McNatty KP, Cambridge LM, Laitinen MPE, Juengel JL, Jokiranta TS, McLaren RJ, Luiro K, Dodds KG, Montgomery GW, Beattie AE, Davis GH, Ritvos O. 2000. Mutations in an oocyte-derived growth factor gene (BMP15) cause increased ovulation rate and infertility in a dosagesensitive manner. Nat Genet, 25:279-283.

Garcia-Guerra A, Kamalludin MH, Kirkpatrick BW, Wiltbank MC. 2018. Trio a novel bovine highfecundity allele: II. Hormonal profile and follicular dynamics underlying the high ovulation rate. Biol Reprod, 98:335-349.

Gebremedhn S, Salilew-Wondim D, Ahmad I, Sahadevan S, Hossain MM, Hoelker M, Rings F, Neuhoff C, Tholen E, Looft C, Schellander K, Tesfaye D. 2015. MicroRNA expression profile in bovine granulosa cells of preovulatory dominant and subordinate follicles during the late follicular phase of the estrous cycle. PLoS One, 10:e125912. doi: 10.1371/journal.pone.0125912.

Ginther OJ. 2016. The theory of follicle selection in cattle. Domest Anim Endocrinol, 57:85-99.

Ginther OJ, Siddiqui MAR, Baldrighi JM, Hoffman MM. 2016. Stimulation of regressing subordinate follicles of wave 2 with a gonadotropin product in heifers. Domest Anim Endocrinol, 55:46-50.

Girard A, Dufort I, Douville G, Sirard M-A. 2015. Global gene expression in granulosa cells of growing, plateau and atretic dominant follicles in cattle. Reprod Biol Endocrinol, 13:17. doi: 10.1186/s12958-015-00107.

Glister C, Kemp CF, Knight PG. 2004. Bone morphogenetic protein (BMP) ligands and receptors in bovine ovarian follicle cells: actions of BMP-4, -6 and 7 on granulosa cells and differential modulation of Smad-1 phosphorylation by follistatin. Reproduction, 127:239-254.

Glister C, Richards SL, Knight PG. 2005. Bone morphogenetic proteins (BMP) $-4,-6$, and -7 potently suppress basal and luteinizing hormone-induced androgen production by bovine theca interna cells in primary culture: could ovarian hyperandrogenic dysfunction be caused by a defect in thecal BMP signaling? Endocrinology, 146:1883-1892.

Glister C, Satchell L, Knight PG. 2010. Changes in expression of bone morphogenetic proteins (BMPs), their receptors and inhibin co-receptor betaglycan during bovine antral follicle development: inhibin can antagonize the suppressive effect of BMPs on thecal androgen production. Reproduction, 140:699-712.

Glister C, Satchell L, Knight PG. 2011. Granulosal and thecal expression of bone morphogenetic proteinand activin-binding protein mRNA transcripts during bovine follicle development and factors modulating 
their expression in vitro. Reproduction, 142:581-591. Gong JG, McBride D, Bramley TA, Webb R. 1993. Effects of recombinant bovine somatotrophin, insulinlike growth factor-I and insulin on the proliferation of bovine granulosa cells in vitro. $J$ Endocrinol, 139:67-75. Guerrero-Netro HM, Chorfi Y, Price CA. 2015. Effects of the mycotoxin deoxynivalenol on steroidogenesis and apoptosis in granulosa cells. Reproduction, 149:555-561.

Guerrero-Netro HM, Estienne A, Chorfi Y, Price CA. 2017. The mycotoxin metabolite deepoxydeoxynivalenol increases apoptosis and decreases steroidogenesis in bovine ovarian theca cells. Biol Reprod, 97:746-757.

Han P, Guerrero-Netro H, Estienne A, Cao B, Price CA. 2017. Regulation and action of early growth response 1 in bovine granulosa cells. Reproduction, 154:547-557.

Hatzirodos N, Nigro J, Irving-Rodgers HF, Vashi AV, Hummitzsch K, Caterson B, Sullivan TR, Rodgers RJ. 2012. Glycomic analyses of ovarian follicles during development and atresia. Matrix Biol, 31:45-56.

Hatzirodos N, Irving-Rodgers HF, Hummitzsch K, Rodgers RJ. 2014. Transcriptome profiling of the theca interna from bovine ovarian follicles during atresia. PLoS One, 9:e99706. doi: 10.1371/journal.pone.0099706.

Heath DA, Pitman JL, McNatty KP. 2017. Molecular forms of ruminant BMP15 and GDF9 and putative interactions with receptors. Reproduction, 154:521-534.

Hu CL, Cowan RG, Harman RM, Porter DA, Quirk SM. 2001. Apoptosis of bovine granulosa cells after serum withdrawal is mediated by Fas antigen (CD95) and Fas ligand. Biol Reprod, 64:518-526.

Hussein TS, Froiland DA, Amato F, Thompson JG, Gilchrist RB. 2005. Oocytes prevent cumulus cell apoptosis by maintaining a morphogenic paracrine gradient of bone morphogenetic proteins. $J$ Cell Sci, 118:5257-5268.

Ireland JJ, Roche JF. 1983. Development of nonovulatory antral follicles in heifers: changes in steroids in follicular fluid and receptors for gonadotropins. Endocrinology, 112:150-156.

Ireland JJ, Mihm M, Austin E, Diskin MG, Roche JF. 2000. Historical perspective of turnover of dominant follicles during the bovine estrous cycle: key concepts, studies, advancements, and terms. J Dairy Sci, 83:1648-1658.

Irving-Rodgers HF, van Wezel IL, Mussard ML, Kinder JE, Rodgers RJ. 2001. Atresia revisited: two basic patterns of atresia of bovine antral follicles. Reproduction, 122:761-775.

Jiang Z, Guerrero-Netro HM, Juengel JL, Price CA. 2013. Divergence of intracellular signaling pathways and early response genes of two closely related fibroblast growth factors, FGF8 and FGF18, in bovine ovarian granulosa cells. Mol Cell Endocrinol, 375:97105.

Juengel JL, Reader KL, Bibby AH, Lun S, Ross I, Haydon LJ, McNatty KP. 2006. The role of bone morphogenetic proteins 2, 4, 6 and 7 during ovarian follicular development in sheep: contrast to rat.
Reproduction, 131:501-513.

Knight PG, Glister C. 2006. TGF- $\beta$ superfamily members and ovarian follicle development. Reproduction 132:191-206.

Ko JCH, Kastelic JP, Del Campo MR, Ginther OJ. 1991. Effects of a dominant follicle on ovarian follicular dynamics during the oestrous cycle in heifers. $J$ Reprod Fertil, 91:511-519.

Li J, Hu L, Tian C, Lu F, Wu J, Liu L. 2015. microRNA-150 promotes cervical cancer cell growth and survival by targeting FOXO4. BMC Molecular Biology, 16:24. doi: 10.1186/s12867-015-0052-6.

Li Y, Chen D, Jin LU, Liu J, Li Y, Su Z, Qi Z, Shi MIN, Jiang Z, Yang S, Gui Y, Mao X, Wu X, Lai Y. 2016. Oncogenic microRNA-142-3p is associated with cellular migration, proliferation and apoptosis in renal cell carcinoma. Oncol Lett, 11:1235-1241.

Liang A, Salzano A, D'Esposito M, Comin A, Montillo M, Yang L, Campanile G, Gasparrini B. 2016. Anti-Mullerian hormone (AMH) concentration in follicular fluid and mRNA expression of AMH receptor type II and LH receptor in granulosa cells as predictive markers of good buffalo (Bubalus bubalis) donors. Theriogenology, 86:963-970.

Lin JY, Pitman-Crawford JL, Bibby AH, Hudson NL, McIntosh CJ, Juengel JL, McNatty KP. 2012. Effects of species differences on oocyte regulation of granulosa cell function. Reproduction, 144:557-567.

Lv L, Jimenez-Krassel F, Sen A, Bettegowda A, Mondal M, Folger JK, Lee KB, Ireland JJ, Smith GW. 2009. Evidence supporting a role for cocaine- and amphetamine-regulated transcript (CARTPT) in control of granulosa cell estradiol production associated with dominant follicle selection in cattle. Biol Reprod, 81:580-586.

Martinez-Royo A, Jurado JJ, Smulders JP, Martí JI, Alabart JL, Roche A, Fantova E, Bodin L, Mulsant P, Serrano M, Folch J, Calvo JH. 2008. A deletion in the bone morphogenetic protein 15 gene causes sterility and increased prolificacy in Rasa Aragonesa sheep. Anim Genet, 39:294-297.

Mazerbourg S, Monget P. 2018. Insulin-like growth factor binding proteins and IGFBP proteases: a dynamic system regulating the ovarian folliculogenesis. Front Endocrinol, 9:134. doi: 10.3389/fendo.2018.00134.

McNatty KP, Juengel JL, Reader KL, Lun S, Myllymaa S, Lawrence SB, Western A, Meerasahib MF, Mottershead DG, Groome NP, Ritvos O, Laitinen MP. 2005. Bone morphogenetic protein 15 and growth differentiation factor 9 co-operate to regulate granulosa cell function in ruminants. Reproduction, 129:481-487.

Mihm M, Good TEM, Ireland JLH, Ireland JJ, Knight PG, Roche JF. 1997. kuDecline in serum follicle-stimulating hormone concentrations alters key intrafollicular growth factors involved in selection of the dominant follicle in heifers. Biol Reprod, 57:13281337.

Mihm M, Baker PJ, Ireland JL, Smith GW, Coussens PM, Evans AC, Ireland JJ. 2006. Molecular evidence that growth of dominant follicles involves a reduction in follicle-stimulating hormone dependence 
and an increase in luteinizing hormone dependence in cattle. Biol Reprod, 74:1051-1059.

Monniaux D, Pisselet C. 1992. Control of proliferation and differentiation of ovine granulosa cells by insulinlike growth factor-I and follicle-stimulating hormone in vitro. Biol Reprod, 46:109-119.

Monniaux D, Clemente Nd, Touzé J-L, Belville C, Rico C, Bontoux M, Picard J-Y, Fabre S. 2008. liIntrafollicular steroids and anti-Müllerian hormone during normal and cystic ovarian follicular development in the cow. Biol Reprod, 79:387-396.

Mottershead DG, Sugimura S, Al-Musawi SL, Li JJ, Richani D, White MA, Martin GA, Trotta AP, Ritter LJ, Shi J, Mueller TD, Harrison CA, Gilchrist RB. 2015. Cumulin, an oocyte-secreted heterodimer of the transforming growth factor- $\beta$ family, is a potent activator of granulosa cells and improves oocyte quality. J Biol Chem, 290:24007-24020.

Mulsant P, Lecerf F, Fabre S, Schibler L, Monget P, Lanneluc I, Pisselet C, Riquet J, Monniaux D, Callebaut I, Cribiu E, Thimonier J, Teyssier J, Bodin L, Cognié Y, Chitour N, Elsen J-M. 2001. Mutation in bone morphogenetic protein receptor-IB is associated with increased ovulation rate in Booroola Mérino ewes. Proc Natl Sci USA, 98:5104-5109.

Nicol L, Bishop SC, Pong-Wong R, Bendixen C, Holm L-E, Rhind SM, McNeilly AS. 2009. Homozygosity for a single base-pair mutation in the oocyte-specific GDF9 gene results in sterility in Thoka sheep. Reproduction, 138:921-933.

Nivet A-L, Vigneault C, Blondin P, Sirard M-A. 2013. Changes in granulosa cells' gene expression associated with increased oocyte competence in bovine. Reproduction, 145:555-565.

Pierre A, Estienne A, Racine C, Picard J-Y, Fanchin R, Lahoz B, Alabart JL, Folch J, Jarrier P, Fabre S, Monniaux D, di Clemente N. 2016. The bone morphogenetic protein 15 up-regulates the antiMüllerian hormone receptor expression in granulosa cells. J Clin Endocrinol Metab, 101:2602-2611.

Portela VM, Machado M, Buratini J, Jr., Zamberlam G, Amorim RL, Goncalves P, Price CA. 2010. Expression and function of fibroblast growth factor 18 in the ovarian follicle in cattle. Biol Reprod, 83:339-346.

Portela VM, Dirandeh E, Guerrero-Netro HM, Zamberlam G, Barreta MH, Goetten AF, Price CA. 2015. The role of fibroblast growth factor-18 in follicular atresia in cattle. Biol Reprod, 92:14. doi: 10.1095/biolreprod.114.121376.

Porter DA, Vickers SL, Cowan RG, Huber SC, Quirk SM. 2000. Expression and function of Fas antigen vary in bovine granulosa and theca cells during ovarian follicular development and atresia. Biol Reprod, 62:62-66.

Price CA, Webb R. 1988. Steroid control of gonadotropin secretion and ovarian function in heifers. Endocrinology, 122:2222-2231.

Price CA, Carrière PD, Bhatia B, Groome NP. 1995. Comparison of hormonal and histological changes during follicular growth, as measured by ultrasonography, in cattle. J Reprod Fertil, 103:63-68.
Quirk SM, Harman RM, Cowan RG. 2000. Regulation of Fas antigen (Fas, CD95)-mediated apoptosis of bovine granulosa cells by serum and growth factors. Biol Reprod, 63:1278-1284.

Quirk SM, Cowan RG, Harman RM. 2006. The susceptibility of granulosa cells to apoptosis is influenced by oestradiol and the cell cycle. $J$ Endocrinol, 189:441-453.

Rajesh G, Mishra SR, Paul A, Punetha M, Vidyalakshmi GM, Narayanan K, Bag S, Bhure SK, Singh Chouhan V, Maurya VP, Singh G, Sarkar M. 2018. Transcriptional and translational abundance of Bone morphogenetic protein (BMP) 2, 4, 6, 7 and their receptors BMPR1A, 1B and BMPR2 in buffalo ovarian follicle and the role of BMP4 and BMP7 on estrogen production and survival of cultured granulosa cells. Res Vet Sci, 118:371-388.

Rico C, Médigue C, Fabre S, Jarrier P, Bontoux M, Clément F, Monniaux D. 2011. Regulation of antiMüllerian hormone production in the cow: a multiscale study at endocrine, ovarian, follicular, and granulosa cell levels. Biol Reprod, 84:560-571.

Rivera GM, Fortune JE. 2001. Development of codominant follicles in cattle is associated with a follicle-stimulating hormone-dependent insulin-like growth factor binding protein-4 protease. Biol Reprod, 65:112-118.

Roberts AJ, Echternkamp SE. 2003. Insulin-like growth factor binding proteins in granulosa and thecal cells from bovine ovarian follicles at different stages of development1,2. J Anim Sci, 81:2826-2839.

Rosenfeld CS, Wagner JS, Roberts RM, Lubahn DB. 2001. Intraovarian actions of oestrogen. Reproduction, 122:215-226.

Salilew-Wondim D, Ahmad I, Gebremedhn S, Sahadevan S, Hossain MDM, Rings F, Hoelker M, Tholen E, Neuhoff C, Looft C, Schellander K, Tesfaye D. 2014. The expression pattern of microRNAs in granulosa cells of subordinate and dominant follicles during the early luteal phase of the bovine estrous cycle. PLoS One, 9:e106795. doi: 10.1371/journal.pone. 0106795.

Sang W, Sun C, Zhang C, Zhang D, Wang Y, Xu L, Zhang Z, Wei X, Pan B, Yan D, Zhu F, Yan Z, Cao J, Loughran TP, Xu K. 2016. MicroRNA-150 negatively regulates the function of $\mathrm{CD} 4+\mathrm{T}$ cells through AKT3/Bim signaling pathway. Cell Immunol, 306/307:35-40.

Schreiber NB, Spicer LJ. 2012. Effects of fibroblast growth factor 9 (FGF9) on steroidogenesis and gene expression and control of FGF9 mRNA in bovine granulosa cells. Endocrinology, 153:4491-4501.

Schütz LF, Schreiber NB, Gilliam JN, Cortinovis C, Totty ML, Caloni F, Evans JR, Spicer LJ. 2016. Changes in fibroblast growth factor $9 \mathrm{mRNA}$ in granulosa and theca cells during ovarian follicular growth in dairy cattle. J Dairy Sci, 99:9143-9151.

Selvaraju S, Folger JK, Gupta PSP, Ireland JJ, Smith GW. 2013. Stage-specific expression and effect of bone morphogenetic protein 2 on bovine granulosa cell estradiol production: regulation by cocaine and amphetamine regulated transcript. Domest Anim 
Endocrinol, 44:115-120.

Shimizu T, Magata F, Abe Y, Miyamoto A. 2012 Bone morphogenetic protein 4 (BMP-4) and BMP-7 induce vascular endothelial growth factor expression in bovine granulosa cells. Anim Sci J, 83:663-667.

Shimizu T. 2016. Molecular and cellular mechanisms for the regulation of ovarian follicular function in cows. J Reprod Dev, 62:323-329.

Siddiqui MAR, Baldrighi JM, Greene JM, Wolf CA, Ginther OJ. 2015. Spontaneous and experimental conversion of a regressing subordinate follicle of wave 1 to the dominant follicle of wave 2 in heifers. Theriogenology, 83:1352-1359.

Sontakke SD, Mohammed BT, McNeilly AS, Donadeu FX. 2014. Characterization of microRNAs differentially expressed during bovine follicle development. Reproduction, 148:271-283.

Souza CJ, MacDougall C, MacDougall C, Campbell BK, McNeilly AS, Baird DT. 2001. The Booroola (FecB) phenotype is associated with a mutation in the bone morphogenetic receptor type $1 \mathrm{~B}$ (BMPR1B) gene. J Endocrinol, 169:R1-R6.

Souza CJ, Campbell BK, McNeilly AS, Baird DT. 2002. Effect of bone morphogenetic protein 2 (BMP2) on oestradiol and inhibin A production by sheep granulosa cells, and localization of BMP receptors in the ovary by immunohistochemistry. Reproduction, 123:363-369.

Spicer LJ, Alpizar E, Echternkamp SE. 1993. Effects of insulin, insulin-like growth factor I, and gonadotropins on bovine granulosa cell proliferation, progesterone production, estradiol production, and(or) insulin-like growth factor I production in vitro. J Anim
Sci, 71:1232-1241.

Spicer LJ, Aad PY, Allen DT, Mazerbourg S, Payne AH, Hsueh AJ. 2008. Growth differentiation factor 9 (GDF9) stimulates proliferation and inhibits steroidogenesis by bovine theca cells: influence of follicle size on responses to GDF9. Biol Reprod, 78:243-253.

Stock AE, Fortune JE. 1993. Ovarian follicular dominance in cattle: relationship between prolonged growth of the ovulatory follicle and endocrine parameters. Endocrinology, 132:1108-1114.

Webb R, Buratini J, Hernandez-Medrano JH, Gutierrez CG, Campbell BK. 2016. Follicle development and selection: past, present and future. Anim Reprod, 13:234-249.

Yamashita H, Murayama C, Takasugi R, Miyamoto A, Shimizu T. 2011. BMP-4 suppresses progesterone production by inhibiting histone $\mathrm{H} 3$ acetylation of StAR in bovine granulosa cells in vitro. Mol Cell Biochem, 348:183-190.

Yan C, Wang P, DeMayo J, DeMayo FJ, Elvin JA, Carino C, Prasad SV, Skinner SS, Dunbar BS, Dube JL, Celeste AJ, Matzuk MM. 2001. Synergistic roles of bone morphogenetic protein 15 and growth differentiation factor 9 in ovarian function. Mol Endocrinol, 15:854-866.

Zamberlam G, Portela V, de Oliveira JF, Goncalves PB, Price CA. 2011. Regulation of inducible nitric oxide synthase expression in bovine ovarian granulosa cells. Mol Cell Endocrinol, 335:189-194.

Zielak-Steciwko AE, Evans ACO. 2016. Genomic portrait of ovarian follicle growth regulation in cattle. Reprod Biol, 16:197-202. 